\title{
Distribution of Xylella fastidiosa in Blueberry Stem and Root Sections in Relation to Disease Severity in the Field
}

\author{
R. M. Holland, R. S. C. Christiano, E. Gamliel-Atinsky, and H. Scherm, Department of Plant Pathology, University of Georgia,
} Athens 30602

\begin{abstract}
Holland, R. M., Christiano, R. S. C., Gamliel-Atinsky, E., and Scherm, H. 2014. Distribution of Xylella fastidiosa in blueberry stem and root sections in relation to disease severity in the field. Plant Dis. 98:443-447.

Xylella fastidiosa causes bacterial leaf scorch, a new disease of southern highbush blueberry in the southeastern United States. Infections occlude the xylem of affected plants, causing drought-like symptoms and, eventually, plant death. To assess the likelihood of mitigation of bacterial leaf scorch through cultural practices such as pruning or hedging of affected plants, we determined the localization and population density of $X$. fastidiosa in naturally infected blueberry plants with varying levels of bacterial leaf scorch severity. Stem segments were sampled from the current season's growth down to the base of the plant, as were root segments on plants that were either asymptomatic or had light, moderate, or severe symptoms in three plantings affected by the disease. Stem sap was extracted from each segment and population densities of $X$. fastidiosa were determined using real-time polymerase chain reaction with species-specific primers. Detection frequencies were lowest (but non-zero) in sap from asymptomatic plants and highest in plants with severe symptoms. In asymptomatic plants,

detection was generally least frequent ( 0 to $20.0 \%$ ) in top and root sections and highest (4.6 to 55.6\%) in middle and base stem sections. As disease severity increased, detection frequencies in roots increased to $>80 \%$ in two plantings and to $60 \%$ in the third planting. Overall, detection frequencies were highest $(>80 \%)$ in middle and base stem sections of plants from the moderate and severe disease classes. The lowest bacterial titers (averaging 0 to $2.1 \times 10^{1} \mathrm{CFU}$ per $50 \mu \mathrm{l}$ of sap) were observed in top and root sections of asymptomatic plants, whereas the highest titers (generally between $10^{4}$ and $10^{5}$ CFU per 50 $\mu l$ of sap) were obtained from middle, base, and root sections of plants from the moderate and severe classes. The presence of the bacterium in middle and base stem sections at low disease severity indicates rapid distribution of $X$. fastidiosa in affected plants. Because the pathogen accumulates in the roots at moderate and high disease severity levels, management strategies such as pruning and mowing are unlikely to be effective in curing affected plants from bacterial leaf scorch.
\end{abstract}

Bacterial leaf scorch, caused by the xylem-limited bacterium $X y$ lella fastidiosa, is a lethal disease of susceptible southern highbush blueberry cultivars (Vaccinium corymbosum interspecific hybrids) such as 'Star', 'FL 86-19', and 'Rebel' $(3,4)$. Symptoms include marginal necrosis of the leaves, yellowing of stems, dieback, and, eventually, plant death. The bacterium is vectored by xylem-feeding leafhoppers, of which the glassy-winged sharpshooter $\mathrm{Ho}$ malodisca vitripennis is most prevalent in blueberry plantings in southern Georgia (16).

Field surveys conducted in 2007 indicated that bacterial leaf scorch was widespread and damaging on susceptible cultivars in the Georgia blueberry belt (3). Currently, management options are limited to the use of resistant cultivars (such as 'Emerald') in new plantings and application of insecticides for control of the vector in existing plantings. The latter approach is hampered by concerns about appropriate application timing, limited efficacy of active ingredients, and potential for overuse of insecticides. This prompted the investigation of cultural practices for managing the disease, such as pruning to remove infected tissues in order to slow or prevent disease increase and plant death.

Corresponding author: H. Scherm, E-mail scherm@uga.edu

Current address of R. M. Holland: University of Georgia, Bacon County Cooperative Extension, Alma 31510.

Current address of R. S. C. Christiano: Clonal Citrus Propagation Program, University of California-Riverside, Lindcove Research and Extension Center, Exeter 93221.

E. Gamliel-Atinsky is deceased.

Accepted for publication 25 October 2013.

http://dx.doi.org/10.1094/PDIS-06-13-0680-RE

(C) 2014 The American Phytopathological Society
Pruning has been used previously for managing diseases caused by $X$. fastidiosa in other hosts. For Pierce's disease of grape, the date of inoculation affects persistence of the bacterium in the field. In northern California, grapevines inoculated earlier in the season (April to May) developed more extensive and severe Pierce's disease symptoms than those inoculated later (June to August) (7). This affected the percentage of vine recovery after the winter, such that only $54 \%$ of vines recovered from the earlier-inoculated batch compared with $88 \%$ of vines from the later-inoculated batch. Mitigation of the disease in the recovered vines was likely associated with late-winter pruning, which may have removed all infected portions of affected canes, thereby leaving the vine uninfected (7).

In coffee, where $X$. fastidiosa causes a bacterial leaf scorch disease, pruning procedures of varying intensity were evaluated for control of disease incidence in two cultivars (15). The three pruning methods assessed were traditional pruning, skeleton cut, and trunking. In traditional pruning, plants were cut $0.5 \mathrm{~m}$ down from the apex of the plant. In skeleton cut, $0.5 \mathrm{~m}$ of the branches from the main trunk of the plant were kept whereas, in trunking, the plants were cut $0.5 \mathrm{~m}$ from the ground. When plants of a severely affected cultivar underwent dramatic pruning such as skeleton cut or trunking, the proportion of stems with xylem vessel obstruction was lowered (15). This indicates that drastic pruning could be advantageous for the control of $X$. fastidiosa when disease incidence is high.

In blueberry, selective pruning, mechanical hedging of tops $(12,18)$, or more aggressive flail-mowing of plants close to ground level could be implemented in an attempt to cure infected plants from $X$. fastidiosa. Whether such strategies will be effective depends on where in the plant the bacterium is located as symptoms start to develop. The pathogen is thought to be inoculated into current-season growth, given that the glassy-winged sharpshooter, the most prevalent potential vector of $X$. fastidiosa in Georgia blueberry plantings, settles and feeds primarily on new growth (17). In 
advanced stages of infection, the pathogen can be isolated from roots of affected southern highbush blueberry plants (4). If X. fastidiosa reaches the roots at early stages of infection, even aggressive pruning would be ineffective in curing affected plants. Thus, it is important to determine the presence or absence of the bacterium in tissue sections of different ages and in plants with varying levels of disease severity. Based on these considerations, the objective of this study was to evaluate the distribution of $X$. fastidiosa in stem and root segments of different age classes (top to bottom of plant) in relation to natural disease severity in field-grown southern highbush blueberry plants.

\section{Materials and Methods}

Sample collection. Three commercial southern highbush blueberry plantings affected by bacterial leaf scorch were sampled for stem and root sections. The plantings were located in Brantley and Bacon counties, GA. FL 86-19 and 'Bluecrisp' (both highly susceptible cultivars) were utilized in 2009 , whereas Star (moderately susceptible) was sampled in 2010. In each field, 10 asymptomatic plants as well as 10 plants each with light, moderate, or severe visual symptoms of bacterial leaf scorch were selected in September or early October when symptoms are most pronounced (total of 40 plants per field, except for Star, where insufficient samples in the light disease severity class were available). Plants in the light severity class exhibited slight to moderate marginal necrosis of the leaves ( $\leq 20 \%$ necrotic area). Moderately severe plants displayed more symptoms, including marginal necrosis of the leaves $(\geq 20 \%$ necrotic area), yellowing of the stems, and some dieback, while maintaining most of their green foliage. Severely affected plants had severe marginal necrosis of the leaves, usually associated with oak-leaf pattern; a higher incidence of yellow stems; severe dieback; and a considerable reduction in green canopy.

Within each plant, a representative (i.e., corresponding to the desired disease severity class) main stem was selected and cut into sections (20 to $35 \mathrm{~cm}$ long) corresponding to different growth age classes (i.e., current year's fall growth, current year's spring growth, last year's growth, and lower trunk sections of different diameter classes for a total of up to six aboveground stem sections per plant) (Fig. 1). These sections were subsequently grouped into three strata for data analysis and presentation: top (current year), middle (previous year), and lower base (older than 1 year) stem sections. For each plant, each stratum had between one and three segments of the appropriate age classes. In addition, a root segment ( 0.5 to $1.5 \mathrm{~cm}$ in diameter) from the same sector within the plant where the stem originated was sampled. The pruning shears were surface disinfested with disinfecting wipes (active ingredients: $0.184 \%$ n-alkyl dimethyl benzyl ammonium chloride and $0.184 \%$ n-alkyl dimethyl ethylbenzyl ammonium chloride; Clorox, Oakland, CA) between cuts. Samples were placed into plastic sample bags and returned to the laboratory on ice.

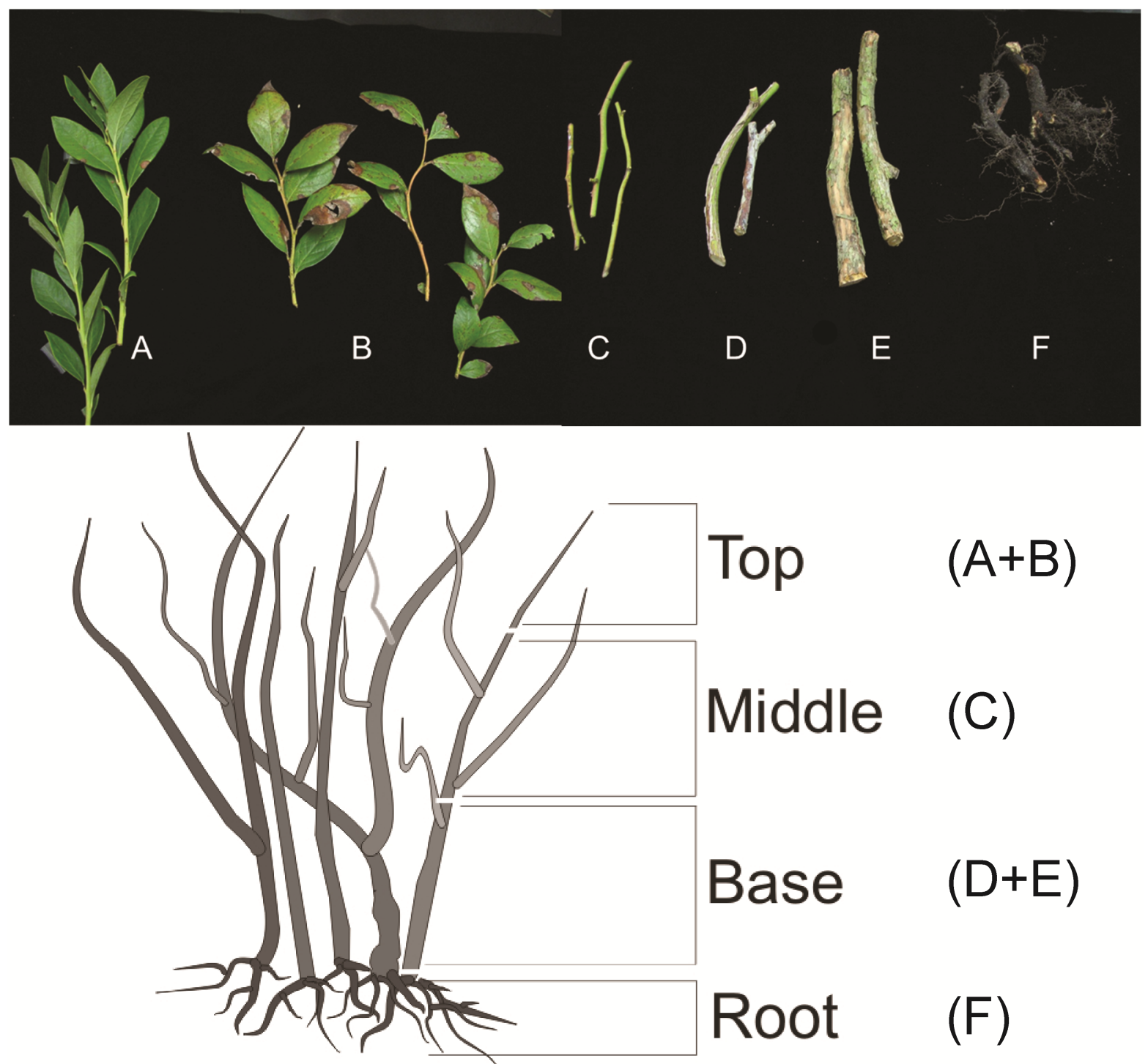

Fig. 1. Stem and root sections used for stem sap sampling to detect Xylella fastidiosa in naturally infected southern highbush blueberry plants in the field. A, Fall growth; B, spring growth; $\mathbf{C}$, previous year's growth; $\mathbf{D}$ and $\mathbf{E}$, progressively older trunk sections; $\mathbf{F}$, roots. 
Stem and root sap extraction and pathogen detection. Segments were trimmed to approximately 15 to $20 \mathrm{~cm}$ in length with an additional fresh cut made to each side of the stem section, and sap was extracted from each stem or root section using mechanical pressure applied with a vise. A micropipette was used to retrieve the extruding sap, which was then collected into sterile microcentrifuge tubes and stored at $-80^{\circ} \mathrm{C}$. To determine bacterial titer in the sap, total DNA was extracted from typically $50 \mu$ of thawed sap using the PowerPlant Pro DNA isolation kit (Mo Bio, Carlsbad, CA) and subjected to real-time polymerase chain reaction (PCR) with species-specific primers elongation factor Tu (EFTu)_3 (Fwd 5-TGA GGT GGA AAT TGT TGG CAT T-3) and EFTu_3 (Rev 5-AGC CTG ACC TTG ATC CAA TAA-3). Stem sap from disease-free Star plants maintained in a greenhouse served as negative controls. PCR primer sequences had been designed with Primer Express software (Applied Biosystems, Foster City, CA) based on the sequence of $X$. fastidiosa (Temecula strain) EFTu (accession number NC_004556), a highly conserved gene among strains of the pathogen. This is the same target gene used previously by Gambetta et al. (8). Specificity was confirmed using strains of $X$. fastidiosa, Acidovorax citrulli, Xanthomonas arboricola pv. pruni, X. axonopodis pv. phaseoli, and Bacillus thuringiensis.

PCR reaction volume was a total of $12 \mu \mathrm{l}$ which included $3 \mu \mathrm{l}$ of template DNA, $6 \mu$ of Power SYBR Green Master Mix (Applied Biosystems), $0.5 \mu \mathrm{l}$ of $10 \mu \mathrm{M}$ forward primer EFTu_3 FW, $0.5 \mu \mathrm{l}$ of $10 \mu \mathrm{M}$ reverse primer EFTu_3 Rev, and $2 \mu \mathrm{l}$ of sterile distilled deionized water. Reaction cycling conditions were an initial cycle at $95^{\circ} \mathrm{C}$ for $10 \mathrm{~min} ; 40$ cycles at alternating $95^{\circ} \mathrm{C}$ for $10 \mathrm{~s}$ and $60^{\circ} \mathrm{C}$ for $1 \mathrm{~min}$; and ending with a melting curve at $95^{\circ} \mathrm{C}$ for $15 \mathrm{~s}, 60^{\circ} \mathrm{C}$ for $1 \mathrm{~min}, 95^{\circ} \mathrm{C}$ for $15 \mathrm{~s}$, and $60^{\circ} \mathrm{C}$ for $15 \mathrm{~s}$. The resulting $\mathrm{Ct}$ values were converted into $\mathrm{CFU}$ per $50 \mu \mathrm{l}$ of sap based on a standard curve obtained from serial dilution of $10^{6} \mathrm{CFU}$ of Xylella fastidiosa DNA in $50 \mu \mathrm{l}$ of sap taken from disease-free Star blueberry plants maintained in the greenhouse.

One-way analysis of variance (PROC GLIMMIX in SAS v. 9.3; SAS Institute) was applied to compare detection data across the four different strata (fixed effect) within each severity class, with plant serving as a blocking variable (random effect). The analysis was done separately for detection incidence (proportion of positive samples) and bacterial titer (CFU per $50 \mu \mathrm{l}$ of sap).

\section{Results}

Detection frequency. Stem sap samples from negative control plants maintained in the greenhouse and included in each real-time PCR assay did not yield any positive detections. For field-collected plants, frequency of detection of $X$. fastidiosa in sap by real-time PCR was lowest (but non-zero) in asymptomatic plants and highest in plants with severe symptoms (Fig. 2). Detection frequencies on a per plant level were $11.4,38.7$, and $3.2 \%$ in asymptomatic plant

Table 1. Overall detection frequency (across all stem and root segments) of Xylella fastidiosa, as determined by real-time polymerase chain reaction, in stem sap from naturally infected southern highbush blueberry plants in three fields sampled in 2009 and $2010^{\mathrm{a}}$

\begin{tabular}{lccc}
\hline & \multicolumn{3}{c}{ Detection frequency (\%) } \\
\cline { 2 - 4 } Disease severity class & 'Bluecrisp' & 'FL 86-19' & 'Star' \\
(2009) & $(\mathbf{2 0 0 9 )}$ & (2010) \\
\hline Asymptomatic & 11.4 & 38.7 & 3.2 \\
Low & 47.7 & 48.6 & $\ldots$ \\
Moderate & 71.4 & 92.7 & 75.4 \\
Severe & 76.8 & 92.1 & 85.2 \\
\hline
\end{tabular}

a Segments sampled shown in Figure 1, with 10 plants (replicates) for each segment type; ... indicates not sampled.

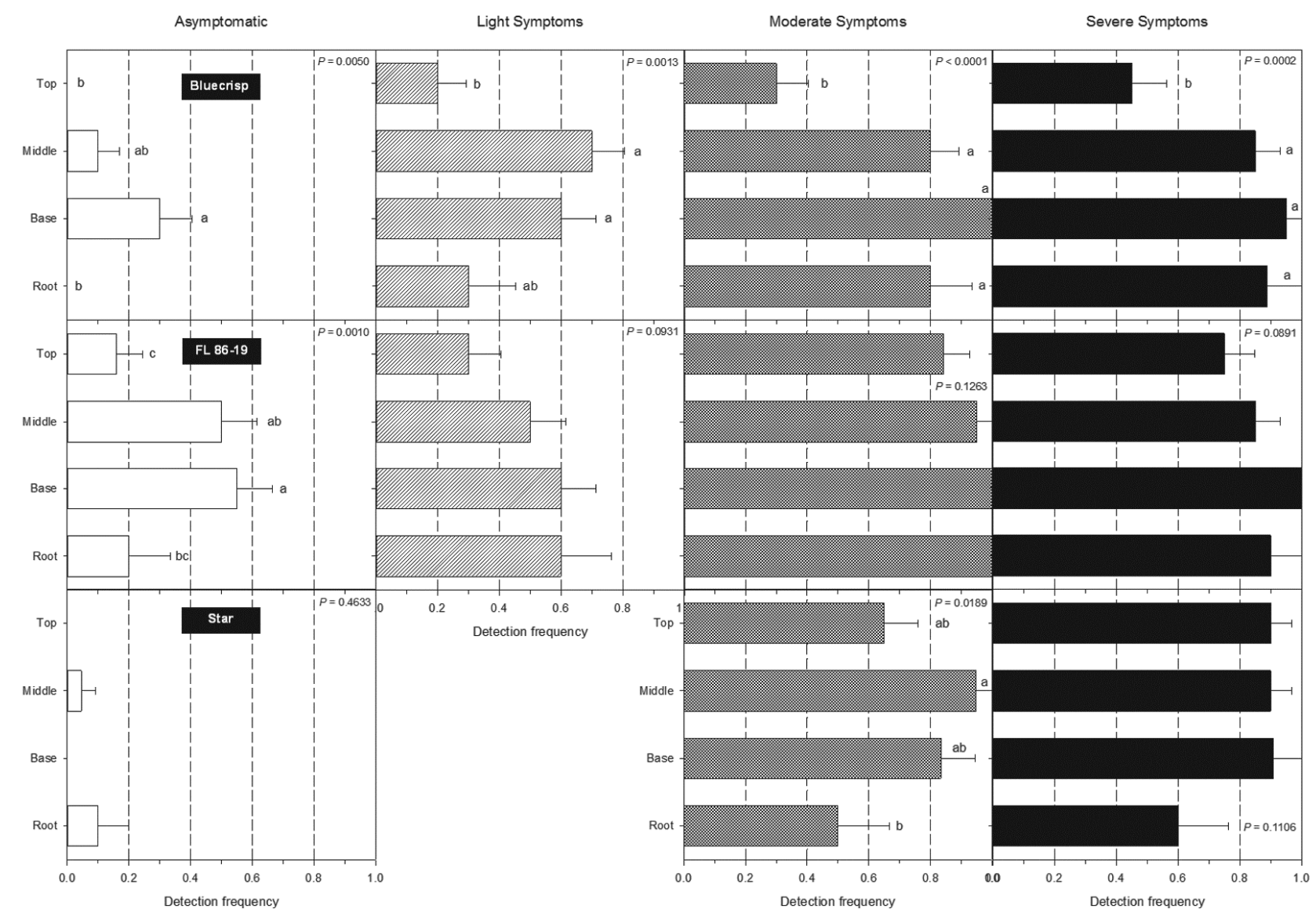

Fig. 2. Detection frequency of Xylella fastidiosa, as determined by real-time polymerase chain reaction, in different stem sections (top to bottom of plant) and roots of 'Bluecrisp', 'FL 86-19', and 'Star' southern highbush blueberry from asymptomatic plants and those having light, moderate, or severe bacterial leaf scorch symptoms. Values are means and standard errors of 10 plants. Within each cultivar and disease severity class, means followed by the same letter are not significantly different according to Tukey's test $(P>0.05)$. No samples were available for Star in the light severity class. 
sections and 76.8, 92.1, and $85.2 \%$ in severe plant sections of Bluecrisp, FL 86-19, and Star, respectively (Table 1). In asymptomatic plants, detection was generally least frequent (zero in the case of Bluecrisp) in top and root sections and highest (up to $55.6 \%$ in the case of FL 86-19) in middle and base stem sections. As disease severity increased, detection frequencies remained lowest in top sections but increased to $>80 \%$ in root sections. A deviation from this pattern was observed in moderately susceptible Star, where detection frequency in the root remained $<60 \%$. Overall, detection frequencies were highest $(>80 \%)$ in middle and base sections of plants from the moderate and severe classes (Fig. 2).

Bacterial titers. Bacterial population densities in stem sap (Fig. 3) closely mirrored the detection frequency data discussed above. The lowest titers, averaging 0 to $2.1 \times 10^{1} \mathrm{CFU}$ per $50 \mu \mathrm{l}$ of sap, were observed in top and root sections of asymptomatic plants, whereas the highest titers (generally between $10^{4}$ and $10^{5} \mathrm{CFU}$ per $50 \mu \mathrm{l}$ of sap) were obtained from middle, base, and root sections of plants from the moderate and severe classes. Moderately susceptible Star had higher bacterial titers in the top, middle, and base stem sections (typically between $10^{3}$ and $10^{4} \mathrm{CFU}$ per $50 \mu \mathrm{l}$ of sap) and lower titers in roots (approximately $10^{2} \mathrm{CFU}$ per $50 \mu \mathrm{l}$ of sap) but these population densities were not significantly different among stem sections and roots $(P>0.05)$. Bacterial populations were higher in FL 86-19 than in the other two cultivars, most likely because of the higher overall disease severity observed in this field (data not shown).

\section{Discussion}

This study suggests that pruning, hedging, or flail-mowing are unlikely to be effective management options for bacterial leaf scorch in southern highbush blueberry. We draw this conclusion based on the high detection frequencies and titers of $X$. fastidiosa in the lower stem sections of symptomatic plants. In addition, the pathogen was readily detected in roots of symptomatic plants, indicating that removal of aboveground plant parts will be ineffective in depleting bacterial reservoirs within the plant.

In a diagnostic context, our findings show that pathogen detection from stem sap is most likely to be successful when testing middle and base stem sections in asymptomatic plants and base stem sections and roots in symptomatic plants. This is based on the evidence that the target pathogen was detected more frequently in these strata and that, even in asymptomatic plants or plants with low disease severity levels, the highest bacterial titer was generally found in the base stem sections. Furthermore, initially, bacterial titer is low in the roots but, as symptoms progress, the bacteria appear to accumulate in the roots. Our results showing high bacterial titer of $X$. fastidiosa in roots is consistent with the study completing Koch's postulates for bacterial leaf scorch of blueberry, in which the pathogen was isolated readily from roots but not from aboveground plant parts (4). Other pathosystems in which $X$. fastidiosa appears to be accumulating in the roots include citrus $(2,9)$ and peach $(1,11)$, in both of which the pathogen causes a stunting disease. Our findings on blueberry seem to contradict the paradigm that the pathogen does not accumulate in the roots of hosts affected by $X$. fastidiosa-induced leaf scorching disease (10).

It is not certain where $X$. fastidiosa is inoculated into blueberry plants. However, because the glassy-winged sharpshooter, the most prevalent potential pathogen vector observed in blueberry plantings in Georgia (16), settles primarily on current and previous season's growth (17), it is likely that the bacterium is inoculated into these sections. From there, the pathogen could spread to lower plant sections by twitching motility, which has been shown to allow other $X$. fastidiosa strains to move basipetally from the inoculation site against the xylem flow $(5,6,13)$. Furthermore, in blueberry,

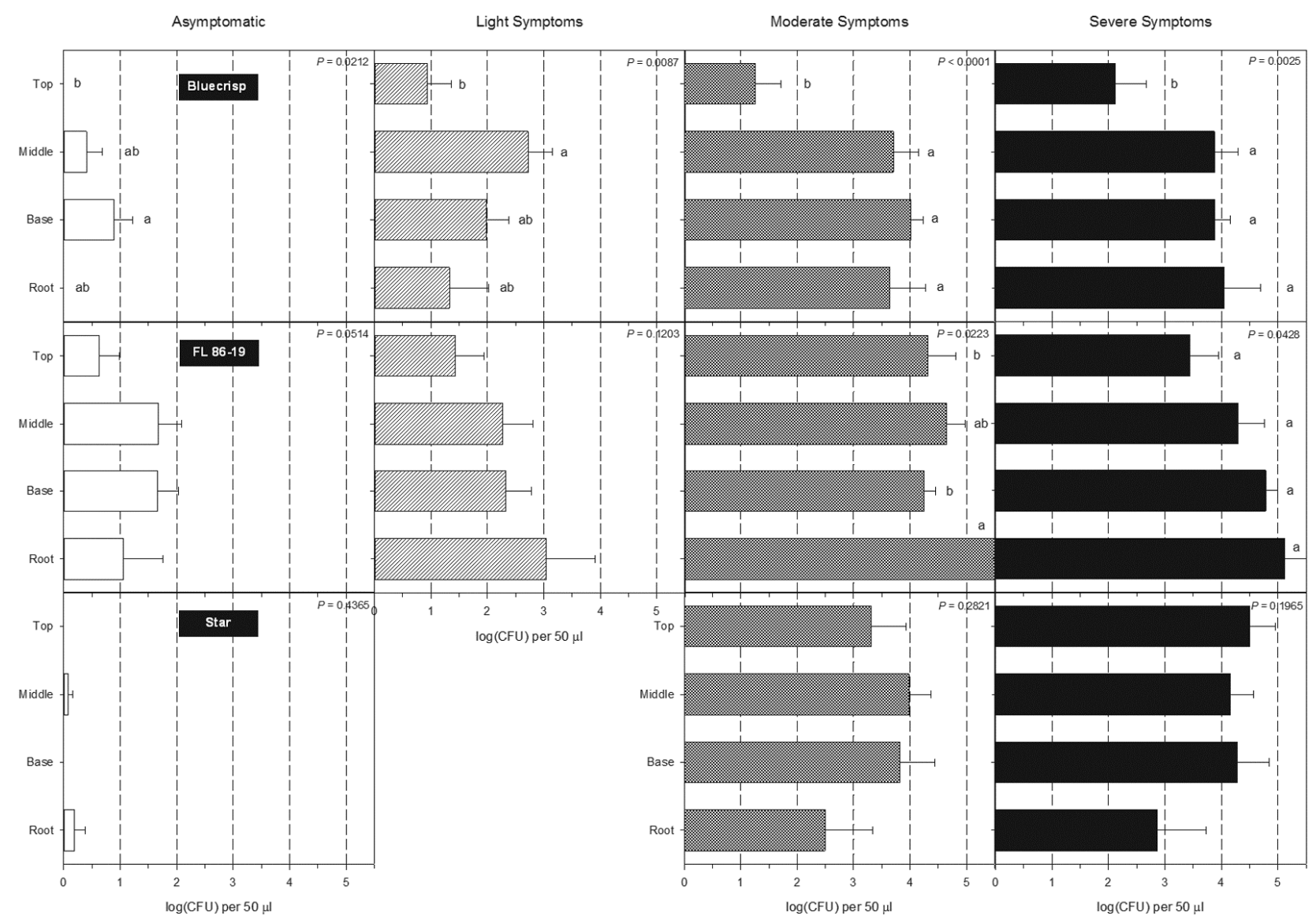

Fig. 3. Titer of Xylella fastidiosa, as determined by real-time polymerase chain reaction, in different stem sections (top to bottom of plant) and roots of 'Bluecrisp', 'FL 86-19', and 'Star' southern highbush blueberry from asymptomatic plants and those having light, moderate, or severe bacterial leaf scorch symptoms. Values are means and standard errors of 10 plants. Within each cultivar and disease severity class, means followed by the same letter are not significantly different according to Tukey's test $(P>$ 0.05). No samples were available for Star in the light severity class. 
previous and current year's shoots may branch off directly from stem base sections; thus, the pathogen may bypass the middle stem sections, reaching the base and roots more quickly than if traversing the full hierarchy of sections from top to bottom of the plant. Another possible explanation for the high bacterial titer in the bottom portions of affected blueberry plants could be inverse hydraulic redistribution (i.e., the downward or lateral movement of water that may occur in plants in certain environmental conditions; 14). In particular, overhead irrigation is used commonly in southern highbush blueberry plantings and could be responsible for creating the conditions for hydraulic redistribution to occur, such that leaves are kept wet while bark mulch or surface soil remains relatively dry. Water would then be taken up by the leaves and redistributed to water-deficient roots by downward movement of xylem fluid. Even if $X$. fastidiosa is inoculated into upper, younger portions of the plant, it could be redistributed readily into base sections and roots through this process. This hypothesis warrants further investigation.

The fact that $X$. fastidiosa was detected in field-collected asymptomatic plants in this study was not surprising. All three field sites sampled had a high incidence of the disease and, as such, it is likely that asymptomatic plants had been exposed to the bacterium. Indeed, detection frequency of the pathogen from asymptomatic plants was highest in FL 86-19 (38.7\%), the field with the highest disease incidence and severity. Yet, average bacterial titers were low even in these plants $(<20$ cells per 50 $\mu \mathrm{l})$. The high prevalence of $X$. fastidiosa-infected plants in our test fields, along with the high sensitivity of the real-time PCR assay used in our study (approximately $10^{2}$ CFU per $50 \mu \mathrm{l}$ of sap), may explain the fact that pathogen detection from asymptomatic plants was not uncommon.

Compared with a study in grape where early infections were pruned out readily in late winter (7), suggesting that the bacterium did not move quickly from distal inoculation sites, the results of our study on blueberry showed that $X$. fastidiosa can be present in the middle and base stem sections of asymptomatic plants and even further in the roots of symptomatic plants. Because our study was conducted on naturally infected plants, we do not know for how long the plants had been infected, nor can we determine how fast the pathogen moves from one stratum to another. Nevertheless, in a practical context, we can conclude that even the use of drastic pruning techniques, such as applied to mitigate bacterial leaf scorch in coffee (15), would likely be ineffective due to the establishment of the pathogen in the lower base sections and roots of the blueberry plant by the time symptoms become apparent.

In conclusion, this study determined the distribution of $X$. fastidiosa in stem and root sections of naturally infected southern highbush blueberry plants, showing that the bacterium is present in lower stem sections and the roots at relatively low levels of disease severity. Therefore, results indicate that pruning, hedging, or flailmowing are unlikely to be effective management options. For routine disease diagnosis, this study also demonstrates that sap from lower stem sections and roots can be tested using real-time PCR to confirm the disease in planta.

\section{Acknowledgments}

We thank J. Jacobs, J.-E. Smith, and D. Stanaland for assistance in locating suitable field sites; and P. Brannen, R. Teskey, and A. Savelle for support and helpful discussions.

\section{Literature Cited}

1. Aldrich, J. H., Gould, A. B., and Martin, F. G. 1992. Distribution of Xylella fastidiosa within roots of peach. Plant Dis. 76: 885-888.

2. Almeida, R. P. P., Pereira, E. F., Purcell, A. H., and Lopes, J. R. S. 2001. Multiplication and movement of a citrus strain of Xylella fastidiosa within sweet orange. Plant Dis. 85:382-386.

3. Brannen, P. M., Scherm, H., and Chang, C. J. 2008. Survey of cultivar differences in bacterial leaf scorch incidence among southern highbush blueberries. Dixie Blueberry News 8:6-7.

4. Chang, C. J., Donaldson, R., Brannen, P., Krewer, G., and Boland, R. 2009. Bacterial leaf scorch, a new blueberry disease caused by Xylella fastidiosa. HortScience 44:413-417.

5. Cursino, L., Galvani, C. D., Athinuwat, D., Zaini, P. A., Li, Y., De La Fuente, L., Hoch, H. C., Burr, T. J., and Mowery, P. 2011. Identification of an operon, Pil-Chp, that controls twitching motility and virulence in Xylella fastidiosa. Mol. Plant-Microbe Interact. 24:1198-1206.

6. De La Fuente, L., Montanes, E., Meng, Y., Li, Y., Burr, T. J., Hoch, H. C., and $\mathrm{Wu}, \mathrm{M}$. 2007. Assessing adhesion forces of type I and type IV pili of Xylella fastidiosa bacteria by use of microfluidic flow chamber. Appl. Environ. Microbiol. 73:2690-2696.

7. Feil, H., Feil, W. S., and Purcell, A. H. 2003. Effects of date of inoculation on the within-plant movement of Xylella fastidiosa and persistence of Pierce's disease within field grapevines. Phytopathology 93:244-251.

8. Gambetta, G. A., Fei, J., Rost, T. L., and Matthews, M. A. 2007. Leaf scorch symptoms are not correlated with bacterial populations during Pierce's disease. J. Exp. Bot. 58:4037-4046.

9. He, C. X., Li, W. B., Ayres, A. J., Hartung, J. S., Miranda, V. S., and Teixeira, D. C. 2000. Distribution of Xylella fastidiosa in citrus rootstocks and transmission of citrus variegated chlorosis between sweet orange plants through natural root grafts. Plant Dis. 84:622-626.

10. Henneberger, T. S. 2003. Effects of low temperature on populations of Xylella fastidiosa in sycamore. M.S. thesis, University of Georgia, Athens.

11. Hutchins, L. M., Cochran, L. C., Turner, W. F., and Weinberger, J. H. 1953. Transmission of phony disease virus from tops of certain affected peach and plum trees. Phytopathology 43:691-696.

12. Krewer, G., Stanaland, D., NeSmith, S., and Mullinix, B. 2004. Post-harvest hedging and pruning of three year pruning trial on 'Climax' and 'Tifblue' rabbiteye blueberry. Small Fruits Rev. 3:203-212.

13. Meng, Y. Z., Li, Y. X., Galvani, C. D., Hao, G. X., Turner, J. N., Burr, T. J., and Hoch, H. C. 2005. Upstream migration of Xylella fastidiosa via pilusdriven twitching motility. J. Bacteriol. 187:5560-5567.

14. Prieto, I., Armas, C., and Pugnaire, F. I. 2012. Water release through plant roots: new insights into its consequences at the plant and ecosystem level. New Phytol. 193:830-841.

15. Queiroz-Voltan, R. B., Cabral, L. P., Paradela Filho, O., and Fazuoli, L. C. 2006. Prune efficiency in the control of Xylella fastidiosa in coffee trees. Bragantia 65:433-440.

16. Tertuliano, M., Scherm, H., and Horton, D. 2010. Population dynamics and feeding preference of the glassy-winged sharpshooter [Homalodisca vitripennis (Germar)] (Hemiptera: Cicadellidae), vector of Xylella fastidiosa, on southern highbush blueberry. In: (Abstr.) Entomol. Soc. Am. 58th Annu. Meet. San Diego, CA.

17. Tertuliano, M., Srinivasan, R., and Scherm, H. 2012. Settling behavior of the glassy-winged sharpshooter, Homalodisca vitripennis, vector of Xylella fastidiosa, on southern highbush blueberry cultivars. Entomol. Exp. Appl. 143:67-73.

18. Williamson, J. G., Davies, F. S., and Lyrene, P. M. 2004. Pruning blueberry plants in Florida. HS985, IFAS Extension, University of Florida, Gainesville. 